\title{
Radiometric survey on the exposure to and management of radioactive waste produced by patients on I131 treatment
}

Elsom José Gomes Santos ${ }^{1}$, Alessandra Sampaio Couto ${ }^{2}$, Higor Leonardo Gomes Santos Martins ${ }^{3}$, Letícia Stella Gomes Santos Martins ${ }^{4}$ and Wolia Costa Gomes ${ }^{5}$

\author{
${ }^{1}$ Universidade CEUMA - UniCEUMA, São Luís-Maranhão, Brasil \\ elsom.jose@ceuma.br \\ ${ }^{2}$ Universidade CEUMA - UniCEUMA, São Luís-Maranhão, Brasil \\ alessandra.sampaio@ceuma.br \\ ${ }^{3}$ Universidade CEUMA - UniCEUMA, São Luís-Maranhão, Brasil \\ enghigorleonardo@outlook.com \\ ${ }^{4}$ Universidade CEUMA - UniCEUMA, São Luís-Maranhão, Brasil \\ leticiastella@gmail.com \\ ${ }^{5}$ Universidade CEUMA - UniCEUMA, São Luís-Maranhão, Brasil \\ woliacg@gmail.com
}

\begin{abstract}
The objective of this study is to perform a radiometric survey on the exposure of Occupationally Exposed Individuals (OEI) to radioactive waste and to evaluate the management of radioactive waste produced by patients treated with Iodine-131 (I131) in a hospital in São Luis, MA, Brazil. For this purpose, radiometric levels were measured using radiation measuring devices placed at strategic points in the hospital bed and the areas surrounding the tailings deposit. For four months, a team of professionals using equations of exposure rate, activity, and equivalent dose analyzed the waste disposal management and the exposure received by the OEI. It was concluded that the discarded waste had a level lower than $2 \mu \mathrm{Ci} / \mathrm{kg}$, thus complying with CNEN 6.05 standard. Patients who were administered I131 with 100 and $150 \mathrm{mCi}$ activity needed to be hospitalized for only 24 hours, while those with $200 \mathrm{mCi}$ activity required 36 to 48 hours of hospitalization. The exposure rate emitted by the wastes in the iodine rooms was $1.95 \mathrm{mR} / \mathrm{h}$ and in the area near the tailings deposit, the OEI received an equivalent dose of $0.01 \mathrm{mSv}$ per week - values below the maximum limit allowed by CNEN 3.01/2014.
\end{abstract}

Keywords: Nuclear medicine; Radioactive waste; Iodine therapy 


\section{Introdution}

Several problems can arise if waste produced by various human activities is not managed properly. These include the contamination of water, soil, and atmosphere, which can irreversibly affect the health of the population (MENDES, 2015).

The Brazilian Legislation mentions several environmental policies. Article 23 of the Federal Constitution of 1988 states that the Union, the States, and the Federal District and Municipalities have the power to protect the environment and fight pollution in any of its forms.

Another example is of Article 225 that gives all Brazilian citizens the right to an ecologically balanced environment, which is a common use of the people and essential for a healthy life. It also highlights the responsibility of the citizens to defend and preserve it for present and future generations (BRASIL, 2016).

In Brazil, in order to standardize actions related to solid health waste management (HWM), the National Environmental Council (CONAMA 358/2005) and the National Health Surveillance Agency (ANVISA 306/2004) regulate and establish guidelines for the management of this waste. Among the guidelines, the main one foresees the expansion of the Plan of Management of Waste of the Health Service (PMWHS) by health establishments. (DIAS GL et al., 2017)

The PMWHS is a document that describes in detail all actions related to the management of HWM in the establishments that operate in the area of Nuclear Medicine (NM) called the Radiation Protection Plan (RPD) and must follow all the steps of Figure 1 (DIAS GL et al., 2017).

Figure 1 - Radioactive Rejects Management, adapted by the authors CNEN-8.01, 2014

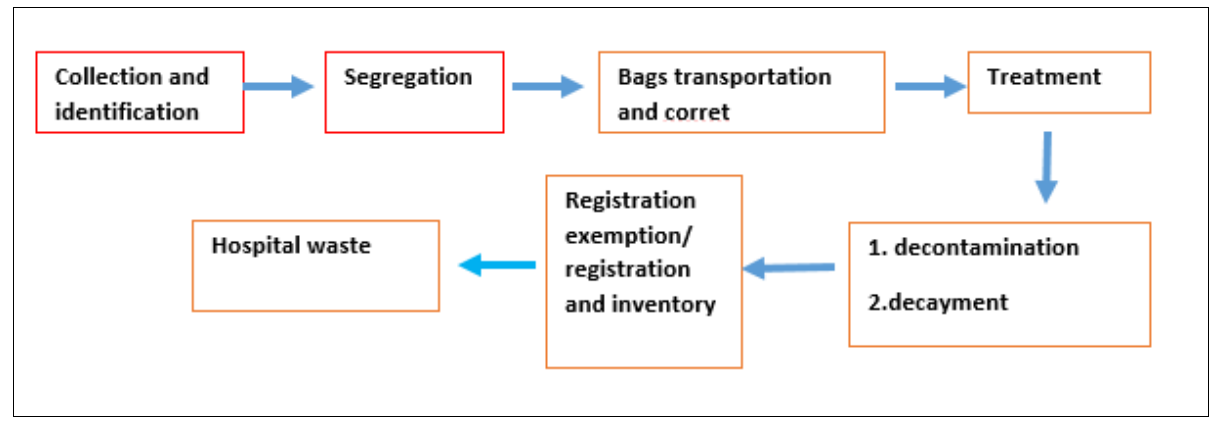

This management or control is of supreme importance due to NM, which performs both diagnostic and therapeutic treatment. Handling, production, possession, and use of sources, as well as the transportation, storage, and segregation of radioactive waste are carried out. To this end, it is necessary to guarantee the safety of Occupationally Exposed Individuals (OEI) working with ionizing radiation, as defined by the CNEN (National Commission for Nuclear Energy) (CNEN 3.01 / 2014) Basic Directive on Radiological Protection.

The therapeutic treatment uses the radioisotope Iodine-131 for hyperthyroidism therapy or treatment of thyroid metastases as it has a half-life of 8.04 days and energy level of gamma rays $364 \mathrm{keV}$ and 0,61 MeV beta. Gamma rays cause higher irradiation because of their energy levels while beta rays are used for therapeutic purposes (CHANG; MOREIRA, 2014). This technique represents approximately $90 \%$ of all NM therapies (KRAWCZYK et al., 2013). 
After the post-operative period of total or partial thyroid thyroidectomy, the patient is given an ablated dose of I131 in order to reduce the recurrence of differentiated thyroid cancer in the long term (COOPER et al., 2006 and PACINI et al., 2006).

Doses are given orally, in liquid form or by capsule, to patients receiving I131 therapy. The advantages of radioactive iodine are easy administration, efficacy, low cost, and absence of pain. When administered orally in sodium iodide solution ( $\mathrm{Nal}$ ), iodine is rapidly absorbed, concentrated, and incorporated by the thyroid into storage follicles (MENDONÇA, 2016).

A comparative study on the cost of treatment with thyroid drugs, radioiodine, or surgery performed in Brazil showed that 1131 treatment was more cost effective and indicated a reduction in glandular volume (CORONHO et al., 2001).

According to CNEN (2013), for treatment after thyroid surgery involving a dose above 1850 Megabecquerel (Mbq) or 50 milicurie $(50 \mathrm{mCi})$, the patient should remain hospitalized in accommodations that meet NE -3.05 / 2013 , Resolution 159 / 13. During the period of hospitalization, the patient is assisted by a qualified team equipped with the knowledge and applicability of radiation protection standards. Some centers recommend repeated low doses $(30 \mathrm{mCi})$, in which case hospital admission is not necessary (BERERHI, 2000 apud RISSATO, 2007).

In the state of Maranhão, the hospital admission procedure is adopted for doses above $30 \mathrm{mCi}$. These doses are administered in a bed characterized as a fourth of the iodine therapy, with the aim to protect the family members, the public, and the environment against possible exposure to radioactive contaminations (CNEN / 2013).

\subsection{Basic Principle of Radiological Protection}

For Silva and Santos (2015), when a patient receives an iodine dose, much of the iodine elimination from the body occurs through urine, sweat, and saliva. The small amount of radioactivity found in this elimination is enough to contaminate the environment and expose people to radiation, inflicting one of the principles of radiation protection called "justification," which describes that no practice involving radiation exposure can be accepted, unless radiation produces benefits for exposed individuals or society (CNEN 3.01/2014)

Therefore, it becomes necessary to use personal protective equipment for professionals who work directly with such patients. The objects used during the period of hospitalization, including personal clothing, bedding and bath, glass, cutlery, and food leftovers, are considered as contaminated materials and should be treated as radioactive waste (SILVA and SANTOS, 2015). These contaminants are segregated in the same place where they are generated and are released only when the rate of their exposure is below $1 \mathrm{mR} / \mathrm{h}$. Then, the waste becomes common hospital waste and can be sent to landfills (SILVA and SANTOS, 2015).

Workers in direct contact with the waste and the patients on iodine treatment are more susceptible to radiological exposure (OLIVEIRA et al., 2016). For this reason, it is necessary to quantify the doses in order to control the radiation exposure to workers. Individual monitoring should be carried out through dosimeters placed on the body (LIRA et al., 2015). Dosimeters are instruments that indicate the exposure or absorbed dose of ionizing radiation in an individual (LIRA et al., 2015).

With the help of the dosimeter, one can estimate the amount of radiation received by professionals and compare it with that established by the Anvisa (secretary of health of sanitary surveillance municipality) $n^{\circ} 453$ / 98 , within the regulations of CNEN 3.01 / 2014 and 3.05 / 2013, where the Cumulative Effective Dose (CED) cannot exceed $20 \mathrm{mSv}$ per year and $4 \mathrm{mSv}$ per month. In the crystalline region $20 \mathrm{mSv}$ per year, hands and feet is $500 \mathrm{mSv}$ per year or $40 \mathrm{mSv}$ 
in any month. If it exceeds this limit, it is necessary to notify the CNEN, justifying the event and detailing the dose rate given to the OEI. (CNEN-NN-3.05.2013).

This research analyzes the management of waste produced by hospitalized patients on Iodine-131 in a hospital in the municipality of São Luís, MA. Substances such as cleaning paper, toilet paper, tissues, towels, sheets, cutlery, plates, sharp objects, and punctures, which cannot be considered as common urban hospital waste, are segregated till they reach an activity of 7,4.104 $\mathrm{Bq} / \mathrm{kg}(2 \mu \mathrm{Ci} / \mathrm{kg})$ and are later disposed as urban hospital waste (6.05 CNEN resolution 167 / 2014).

The objective of this study is to analyze the management of radioactive waste produced by patients on Iodine131 treatment, and to describe the radiometric survey of the patient's exposure during treatment, which is an effective way to evaluate the OEI exposure.

\section{Materials and méthods}

This study was developed in a hospital located in the metropolitan area of São Luís (MA) that contains beds for iodine therapy. Two radiation metering apparatuses with ionization cameras (Figure 2) were used: 1) Victoreen, model 470A - SI series 95671, certified by METROBRAS under No. 17-0615 and 2) Inspector Alert Nuclear Radiation Monitor, series 34885, calibrated by METROBRAS, certification number 17.0640.

Figure 2 - a) Victoreen apparatus and b) Inspector Alert Nuclear Radiation Monitor

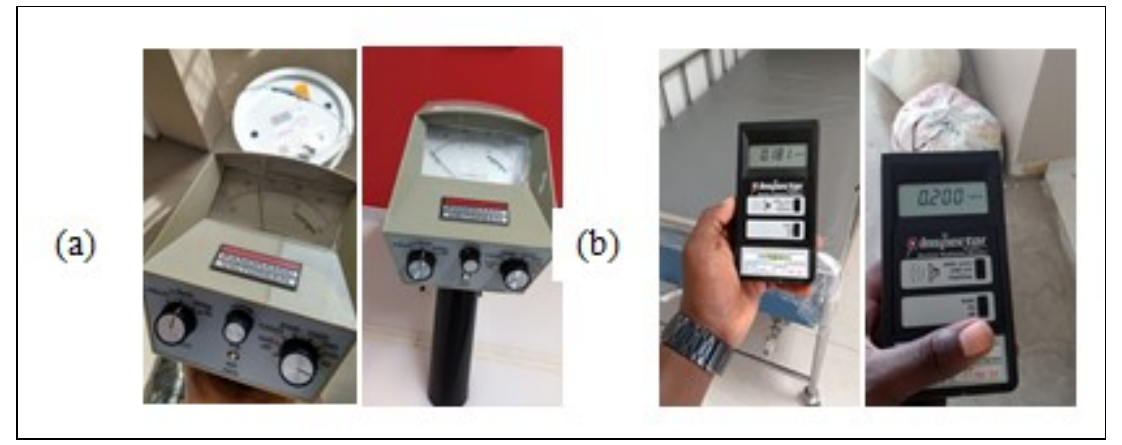

Source: Authors' own

To evaluate the management of segregation, waste collection, and treatment according to CNEN-NN 6.05, for 4 months, a team of professionals collected materials used by patients during a 24-hour stay in two beds of iodine therapy. The standard tailing procedure includes placement of materials in containers labeled with the International Radiation Symbol, along with basic information such as exposure rate, time, and date for possible release as common waste.

However, from the registration and inventory analysis, it was observed that from January 2016 to November 2017, some containers were not labeled with the rate of waste activity for release as common waste in the hospital system. For this reason, two equations were used. Equation 1 determines the rate of exposure,

$$
X=\frac{r \cdot A o}{d^{2}}
$$


where:

$\Gamma$ - specific constant of the gamma radiation, expressed in (R.m2) / (h.Ci);

$\mathrm{d}$ - distance from source in $\mathrm{m}$;

Ao - initial activity, expressed in $\mathrm{Ci}$;

$\mathrm{X}$ - Exposure rate in $\mathrm{R} / \mathrm{h}$.

With the result of the activity at the time of storage (T), Equation 2 was used to determine the final activity of the waste at the time they were discarded (A),

$$
A=\frac{A o}{m} e^{-\left(\ln 2 x \frac{t}{T_{\frac{1}{2}}}\right)}
$$

where:

A - final activity;

A - initial activity;

$\mathrm{m}$ - mass of the tailings in $\mathrm{kg}$;

$\mathrm{t}$ - storage time;

$T_{1 / 2}$ - physical half-life time

The exposure rate constant of a point source ( $\Gamma=$ Iodo131- 0.22 R.m2 / h.Ci) and storage time (t) of 90 days was adopted. With the inventory analysis of the tailings, the quantity generated was obtained, and the condition of radiation rate in storage and disposal was determined.

In order to conduct the radiometric survey of the exposure rates, radiation meters were used, as seen in points 1 to 11 of Figure 3, which refer to the locations inside the iodine room and around the waste deposit.

Figure 3 - Iodine beds low plant floor and radioactive waste deposit

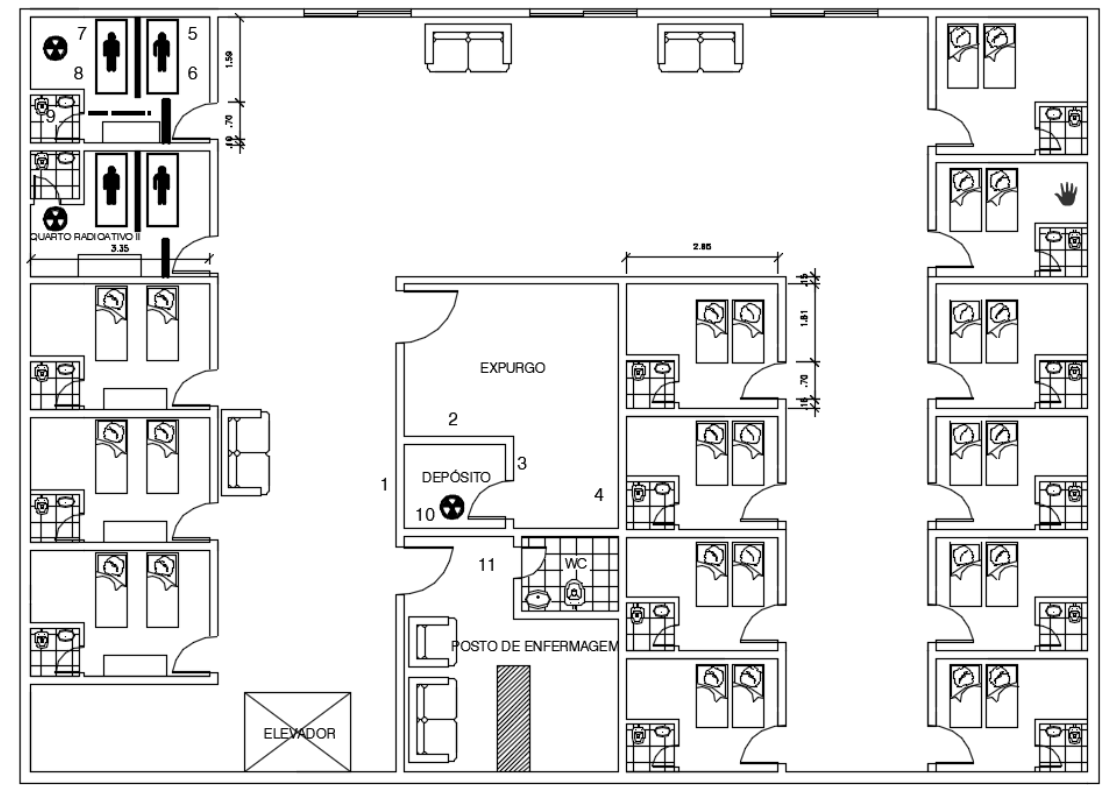

Source: Authors' own 
In order to determine the equivalent dose emitted by the radioactive waste from iodine therapy (item 10), the public and workers due to their location emit ionizing radiation leaving the surrounding areas like the nursing post (item 11), corridor (item 1), and purge (items 1, 2, 3, and 4) more vulnerable to radiation. The reading of the radiation measuring apparatus was undertaken in the points of each area at a distance of $1 \mathrm{~m}$ from the wall. Equation 3 was used to obtain the equivalent dose,

$$
D=L x U \times T
$$

where:

$\mathrm{D}$ - equivalent dose;

$\mathrm{L}$ - reading of the equipment in $\mu \mathrm{Sv} / \mathrm{h}$;

$\mathrm{T}$ - occupational time factor.

The Accumulated Effective Doses (AED) of OEI were determined by the documentary analysis of dosimeters emitted by the Company Technology in Radioprotection LTDA (TEC-RAD) between the years 2015 and 2017. The OEI doses are separated by their areas: Technicians and technologists - T, Nurses - N, Physicists - P, and Nuclear Doctors - ND.

\section{Results and discussion}

Waste management involves collection, segregation, handling, treatment, packaging, transportation, storage, control, and disposal activities (XAVIER, 2012, p.12). Table 1 shows how the team involved in the hospitalization of patients undergoing thyroid treatment with Iodine-131 (I131) implements the storage activity of radioactive waste, which involves inventory of the type of waste, the date that marks the start of I131 decay, waste mass, exposure rate, and exposure rate when released as common hospital waste.

Table 1 - Date collection summary of the release of radioactive waste Iodine 131 from iodine therapy from January 2016 to November 2017

\begin{tabular}{ccccc}
\hline $\begin{array}{c}\text { Reject lot I } \mathbf{~}^{\mathbf{1 3 1}} \\
\text { No. }\end{array}$ & $\begin{array}{l}\text { Storage } \\
\text { Date }\end{array}$ & Mass $(\mathbf{k g})$ & $\begin{array}{c}\text { Exposure one meter } \\
(\mathbf{m R} / \mathbf{h})\end{array}$ & $\begin{array}{c}\text { Activity when released } \\
(\boldsymbol{\mu C i} / \mathbf{k g})\end{array}$ \\
\hline 1 & $10 / 01 / 2016$ & 4 & 0,65 & 0,31 \\
2 & $10 / 01 / 2016$ & 4 & 0,3 & 0,14 \\
3 & $10 / 01 / 2016$ & 4 & 0,35 & 0,16 \\
4 & $10 / 01 / 2016$ & 4 & 0,16 & 0,07 \\
5 & $10 / 01 / 2016$ & 4 & 0,36 & 0,17 \\
6 & $10 / 01 / 2016$ & 4 & 1,55 & 0,74 \\
7 & $12 / 02 / 2016$ & 4 & 1,66 & 0,8 \\
8 & $12 / 02 / 2016$ & 4 & 1,7 & 0,82 \\
9 & $12 / 02 / 2016$ & 4 & 1,45 & 0,7 \\
10 & $12 / 02 / 2016$ & 4 & 0,3 & 0,14 \\
11 & $01 / 03 / 2016$ & 4 & 0,68 & 0,31 \\
12 & $01 / 03 / 2016$ & 4 & 0,65 & 0,31 \\
13 & $06 / 04 / 2016$ & 4 & 0,22 & 0,1 \\
\hline
\end{tabular}


Table 1 - Continuation...

\begin{tabular}{|c|c|c|c|c|}
\hline $\begin{array}{l}\text { Reject lot I }{ }^{131} \\
\text { No. }\end{array}$ & $\begin{array}{l}\text { Storage } \\
\text { Date }\end{array}$ & Mass (kg) & $\begin{array}{c}\text { Exposure one meter } \\
(\mathrm{mR} / \mathrm{h})\end{array}$ & $\begin{array}{l}\text { Activity when released } \\
\qquad(\mu \mathrm{Ci} / \mathrm{kg})\end{array}$ \\
\hline 14 & $06 / 04 / 2016$ & 4 & 0,65 & 0,31 \\
\hline 15 & $06 / 04 / 2016$ & 4 & 0,3 & 0,14 \\
\hline 16 & $22 / 06 / 2016$ & 3,8 & 1,1 & 0,635 \\
\hline 17 & $22 / 06 / 2016$ & 3.3 & 2,45 & 0,2 \\
\hline 18 & $22 / 06 / 2016$ & 4 & 0,84 & 0,34 \\
\hline 19 & $22 / 06 / 2016$ & 2,6 & 1.3 & 1,2 \\
\hline 20 & $13 / 07 / 2016$ & 4,05 & 0,16 & 0,012 \\
\hline 21 & $13 / 07 / 2016$ & 3,8 & 0,22 & 0,024 \\
\hline 22 & $13 / 07 / 2016$ & 3,5 & 1,72 & 1,63 \\
\hline 23 & $13 / 07 / 2016$ & 4 & 1,44 & 1 \\
\hline 24 & $21 / 07 / 2016$ & 1,5 & 0,5 & 0,322 \\
\hline 25 & $21 / 07 / 2016$ & 0,9 & 0,9 & 1,74 \\
\hline 26 & $10 / 08 / 2016$ & 2,8 & 0,85 & 0,49 \\
\hline 27 & $18 / 08 / 2016$ & 4 & 2,2 & 0,128 \\
\hline 28 & 07/09/2016 & 1 & 0,16 & 0,049 \\
\hline 29 & 07/09/2016 & 2 & 1,3 & 1,63 \\
\hline 30 & $12 / 10 / 2016$ & 3,8 & 1,4 & 0,99 \\
\hline 31 & $27 / 10 / 2016$ & 4 & 1,5 & 1,08 \\
\hline 32 & $23 / 11 / 2016$ & 4 & 2,4 & 2,7 \\
\hline 33 & $24 / 11 / 2016$ & 4 & 2,4 & 2,7 \\
\hline \multicolumn{2}{|c|}{ AVERAGE } & 3,55 & 1,01 & 0,66 \\
\hline \multicolumn{2}{|c|}{ Standard Deviation } & 0,92 & 0,73 & 0,71 \\
\hline $\begin{array}{l}\text { Reject lot I } \mathbf{I}^{131} \\
\text { No. }\end{array}$ & $\begin{array}{l}\text { Storage } \\
\text { date }\end{array}$ & Mass (kg) & $\begin{array}{c}\text { Exposure one meter } \\
(\mathrm{mR} / \mathrm{h})\end{array}$ & $\begin{array}{l}\text { Activity when released } \\
\quad(\mu \mathrm{Ci} / \mathrm{kg})\end{array}$ \\
\hline 34 & $18 / 01 / 2017$ & 1,9 & 1,4 & 1,99 \\
\hline 35 & $25 / 01 / 2017$ & 1,5 & 0,16 & 0,33 \\
\hline 36 & $08 / 02 / 2017$ & 4,2 & 1,16 & 0,6 \\
\hline 37 & $23 / 02 / 2017$ & 2,8 & 0,9 & 0.55 \\
\hline 38 & 08/03/2017 & 1,8 & 0,5 & 0,26 \\
\hline 39 & $22 / 03 / 2017$ & 3,3 & 2,4 & 1,37 \\
\hline 40 & $23 / 03 / 2017$ & 3,1 & 1.5 & 1,4 \\
\hline 41 & $05 / 04 / 2017$ & 2,3 & 1,6 & 2.1 \\
\hline 42 & $21 / 04 / 2017$ & 3,8 & 0,21 & 0,022 \\
\hline 43 & $10 / 05 / 2017$ & 1,7 & 0,13 & 0,019 \\
\hline 44 & $10 / 05 / 2017$ & 2,25 & 0,14 & 0,01 \\
\hline 45 & 07/06/2017 & 4,05 & 0,14 & 0,009 \\
\hline 46 & $12 / 06 / 2017$ & 2,2 & 1,2 & 0,55 \\
\hline 47 & $20 / 06 / 2017$ & 1,87 & 1,1 & 0,49 \\
\hline 48 & $26 / 06 / 2017$ & 2,87 & 2,33 & 0,12 \\
\hline 49 & 03/07/2017 & 4 & 0,67 & 0,3 \\
\hline 50 & $10 / 07 / 2017$ & 3,2 & 2,5 & 0,3 \\
\hline
\end{tabular}


Table 1 - Continuation...

\begin{tabular}{|c|c|c|c|c|}
\hline $\begin{array}{l}\text { Reject lot I }{ }^{131} \\
\text { No. }\end{array}$ & $\begin{array}{l}\text { Storage } \\
\text { Date }\end{array}$ & Mass (kg) & $\begin{array}{c}\text { Exposure one meter } \\
(\mathrm{mR} / \mathrm{h})\end{array}$ & $\begin{array}{l}\text { Activity when released } \\
\qquad(\mu \mathrm{Ci} / \mathrm{kg})\end{array}$ \\
\hline 51 & $16 / 07 / 2017$ & 3,7 & 1,55 & 0,97 \\
\hline 52 & $20 / 07 / 2017$ & 4,1 & 1,66 & 0,82 \\
\hline 53 & $02 / 08 / 2017$ & 3,6 & 4,38 & 2,1 \\
\hline 54 & 03/08/2017 & 2,8 & 0,65 & 0,29 \\
\hline 55 & 09/08/2017 & 2,5 & 0,3 & 0,15 \\
\hline 56 & $10 / 08 / 2017$ & 4 & 0,35 & 0,17 \\
\hline 57 & $16 / 08 / 2017$ & 1,8 & 0,38 & 0,19 \\
\hline 58 & $17 / 08 / 2017$ & 4 & 0,86 & 1,65 \\
\hline 59 & $23 / 08 / 2017$ & 4 & 4 & 1,09 \\
\hline 60 & $30 / 08 / 2017$ & 4 & 3,8 & 1,8 \\
\hline 61 & 06/09/2017 & 4 & 1,3 & 1,1 \\
\hline 62 & $13 / 09 / 2017$ & 4 & 4,38 & 2 \\
\hline 63 & $21 / 09 / 2017$ & 3,8 & 1,5 & 0,78 \\
\hline 64 & $28 / 09 / 2017$ & 3,3 & 0,16 & 0,05 \\
\hline 65 & $04 / 10 / 2017$ & 4 & 1,6 & 0,79 \\
\hline 66 & $04 / 10 / 2017$ & 4 & 0,6 & 0,31 \\
\hline 67 & $11 / 10 / 2017$ & 4 & 0,43 & 0,12 \\
\hline 68 & $18 / 10 / 2017$ & 3,3 & 0,45 & 0,17 \\
\hline 69 & $18 / 10 / 2017$ & 4 & 0,85 & 0,36 \\
\hline 70 & $25 / 10 / 2017$ & 4 & 4,3 & 2 \\
\hline 71 & $26 / 10 / 2017$ & 3,8 & 0,45 & 0,16 \\
\hline 72 & $01 / 11 / 2017$ & 4 & 1,3 & 1,18 \\
\hline 73 & $02 / 11 / 2017$ & 4 & 0,9 & 1,78 \\
\hline 74 & $08 / 11 / 2017$ & 3,8 & 2,4 & 1,7 \\
\hline 75 & $15 / 11 / 2017$ & 4 & 1,5 & 1 \\
\hline 76 & $22 / 11 / 2017$ & 4 & 1,6 & 1,45 \\
\hline 77 & $22 / 11 / 2017$ & 4 & 1,9 & 1,82 \\
\hline \multicolumn{2}{|c|}{ AVERAGE } & 3,34 & 1,39 & $\mathbf{0 , 8 0}$ \\
\hline \multicolumn{2}{|c|}{ Standard Deviation } & 0,84 & 1,21 & 0,69 \\
\hline
\end{tabular}

Table 2 shows that the mean annual activity of the tailings when placed as common waste is $0.66 \pm 0.71 \mu \mathrm{Ci} / \mathrm{kg}$ in 2016 and $0.87 \pm 0.83 \mu \mathrm{Ci} / \mathrm{kg}$ in 2017 . This indicates that they are lower than the maximum limit established by the CNEN in accordance with the normative recommendation.

The results obtained in Table 1 show that the iodine therapy rooms produced an average $261 \mathrm{~kg}$ of waste from January 2016 to November 2017 and that the storage conditions and activity rate values for discarding hospital waste was in accordance with the CNEN 6.05 Low and Medium Level Radioactive Waste Management Directive (Resolution 167 / 2017), which establishes the maximum limit for the release of waste as urban waste, that is $2 \mu \mathrm{Ci} / \mathrm{kg}$. 
Table 2 - Data collection mean of the release of radioactive waste I131 from iodine therapy from January 2016 to November 2017

\begin{tabular}{cccc}
\hline $\begin{array}{c}\text { Annual average repository } \\
\text { storage } \mathrm{I}^{131}\end{array}$ & $\begin{array}{c}\text { Mass } \\
\text { average }(\mathrm{kg})\end{array}$ & $\begin{array}{c}\text { Exposure average } 1 \\
\mathrm{~m}(\mathrm{mR} / \mathrm{h})\end{array}$ & $\begin{array}{c}\text { Activity average when } \\
\text { released } \\
(\mu \mathrm{Ci} / \mathrm{kg})\end{array}$ \\
\hline 2016 & $3,5 \pm 0,92$ & $1,01 \pm 0,73$ & $0,66 \pm 0,71$ \\
2017 & $3,34 \pm 0,84$ & $1,39 \pm 1,21$ & $0,80 \pm 0,69$ \\
\hline
\end{tabular}

In Table 2, it can be observed that the average amount of tailings produced per bed was $3.5 \pm 0.92 \mathrm{~kg}$ and $3.34 \pm 0.84 \mathrm{~kg}$ in the years 2016 and 2017 respectively, as compared to the study conducted in Vitória (ES) on the amount of infectious waste generated per bed in hospitals of different legal natures, which showed that in a private hospital the generation of infectious waste was $2.17 \mathrm{~kg}$ in 2014 . The average amount of waste produced by iodine patients is greater because all the bed materials used, such as personal clothing, sheets, towels, cutlery, utensils, and food leftovers, are radioactive waste. Nevertheless, this study is smaller than the one conducted by André et al. (2016) on the generation of health waste in hospitals in Ribeirão Preto (SP).

André et al. (2016) stated that three private hospitals, including a teaching hospital, provided beds for SUS. These hospitals had an average generation of HWM per bed, occupied per day, similar to hospitals in developed countries, with a production of 7.24, 7.80, and $7.80 \mathrm{~kg}$ respectively. In the U.S., hospitals had, on average, a generation of 7 to $10 \mathrm{~kg} 1$ day 1 (WHO, 1999).

U.S. hospitals have a different economic and cultural context as compared to Brazilian hospitals. Therefore, hospitals in Ribeirão Preto that have a large RSS generation may be related to inadequate segregation occurrences (ANDRÉ et al., 2016).

The evaluation conducted in the iodotherapy admissions room showed that the hospital met the requirements of safety and radiological protection for nuclear medicine services, norm CNEN 3.05 (Resolution 159 / 2013), wherein all objects were covered with waterproof plastic material and contained barite walls, doors with $3 \mathrm{~mm}$ lead plates, armored fixed screen with $4 \mathrm{~cm}$ barite, leaded glass for patient visualization, and paviflex bedroom floors and bathrooms with rounded corners to facilitate decontamination.

According to CNEN Standard 3.05, patients enrolled in therapy are discharged after their exposure rate at 2 meters is less than $0.03 \mathrm{mSv} / \mathrm{h}(3 \mathrm{mR} / \mathrm{h})$. This procedure is justified in order to isolate individuals from the public.

Table 3 shows the mean exposure rate of patients who received iodine dose for thyroid treatment after 24 hours, measured at a distance of $2 \mathrm{~m}$.

Table 3 - The mean values of the exposure rate after $24 \mathrm{~h}$ of the patients having ingested iodine I131

\begin{tabular}{cccc}
\hline $\begin{array}{c}\text { Managed activity } \\
(\mathrm{mCi} / \mathrm{MBq})\end{array}$ & $\begin{array}{c}\text { Number of } \\
\text { patients }\end{array}$ & $\begin{array}{c}\text { In-room patient exposure rate } \\
(\mathrm{mR} / \mathrm{h})\end{array}$ & $\begin{array}{c}\text { Out-of-room patient } \\
\text { exposure rate }(\mathrm{mR} / \mathrm{h})\end{array}$ \\
\hline $100 / 3700$ & 6 & $2,71 \pm 0,43$ & $2,00 \pm 0,55$ \\
$150 / 5550$ & 6 & $2,82 \pm 0,23$ & $2,29 \pm 0,47$ \\
$200 / 7400$ & 4 & $8,67 \pm 0,70$ & $7,23 \pm 0,80$ \\
\hline
\end{tabular}


The values observed in Table 3 show that the exposure rates increased for patients within the rooms due to background radiation (known as background or BG), floor contamination, garbage, impermeable furniture plastic, and other contaminated objects.

Campos (2015) evaluated the contribution of surface contamination of the therapeutic room to the extent of the exposure rate of radioiodine patients. From the results obtained, it was concluded that the contaminated surfaces close to the patient did not generate significant values to determine whether or not the patient could be released. However, while measuring the exposure rate of patients in this study, to determine their release, there was an increase in the influence of background radiation from the bathroom (point 9, figure 2), which has the highest exposure rate within the bed. It was found that there was no significant influence on the results for determination of discharge. It is believed that the BG can increase significantly, thus influencing the patient's exposure rate.

In Table 3, patients who ingested I131 with activity of 100 and $150 \mathrm{mCi}$ after 24 hours were giving an exposure rate at $2 \mathrm{~m}$ distance of $2.71 \pm 0.43$ and $2.82 \pm 0.23 \mathrm{mR} / \mathrm{h}$ being the recommended for high of the fourth values lower than $3 \mathrm{mR} / \mathrm{h}$. Patients who received $200 \mathrm{mCi}$ required 36 to 48 hours of hospitalization and their exposure rates at the same distance were $8.67 \pm 0.70 \mathrm{mR} / \mathrm{h}$. A similar interpretation was found in the study by Silva and Santos (2015), where patients on doses between 250 and $400 \mathrm{mCi}$ had a higher exposure rate after 24 hours, with values higher than $3 \mathrm{mR} / \mathrm{h}$.

Dose estimation of exposure to radiation produced by the incorporation of I131 in patients creates difficulties for regulatory authorities of different countries because of the interpretation of the recommendations of the International Atomic Energy Agency (IAEA) and International Commission on Radiological Protection (ICRP). In 2006, the IAEA recommended the level at $1 \mathrm{~m}$ for patient release would be $7 \mathrm{mR} / \mathrm{h}$. The standards of the European Union (EU) to release patients exposed to $1 \mathrm{~m}$ radiation is less than $2 \mathrm{mR} / \mathrm{h}$ (ZHANG et al., 2014). In Brazil, the CNEN before 2013 adopted the distance $1 \mathrm{~m}$ exposure lower than $6,6 \mathrm{mR} / \mathrm{hr}$.

Zhang et al. (2014) in their study with Chinese patients found that exposure doses of patients after 24 hours with activity up to $150 \mathrm{mCi} / 5550 \mathrm{MBq}$ were also below the thresholds for discharge, since China adopts the distance $1 \mathrm{~m}$ exposure rate as $7 \mathrm{mR} / \mathrm{h}$. However, Zhang et al. (2014) still draw attention to the fact that Chinese patients, as compared to patients in the United Kingdom, received a decreased dose of exposure faster, believing race, body type, eating habits, and environmental conditions to be the main cause. The effects of these factors on radiation exposure have not been not investigated so far.

The radiometric survey was conducted in the rooms of iodine therapy (Figure 2) during the period of hospitalization of patients under treatment with I131. An effective mean dose rate of $0.1 \mathrm{mSv}$ was found in 16 patients, which shows that these patients did not present a risk to the health of the OEI and their relatives. However, the contact time should be brief at least for the first 48 hours (limit of $5 \mathrm{mSv}$ for companions or

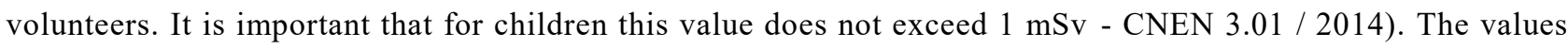
were acquired by points 5 and 6 with distance of $1 \mathrm{~m}$ of the thyroid with $\mathrm{I} 131$ and points 7 and 8 at a distance of $2 \mathrm{~m}$ from the thyroid.

The radioactive waste produced in the rooms of iodine therapy must be stored in the reservoir, according to Figure 3 (item 10). This route is taken by OEI with an average exposure rate of $1.95 \mathrm{mR} / \mathrm{h}$, a dose of 0.017 $\mathrm{mSv}$, and a very low limit of $5 \mathrm{mSv}$, in which the worker was wearing a lead plume of $0.5 \mathrm{~mm}$ lead. These observations were also made by Silva and Santos (2015) in their research on radioactive waste management of 
iodine therapy where the $0.5 \mathrm{~mm}$ lead apron protected the genitourinary region at an exposure rate of $3 \mathrm{mR} / \mathrm{h}$ on the 5-minute path from the team to the tailings deposit.

The evaluation carried out in the hospitalization rooms showed that the hospital met the requirements of safety and radiological protection for nuclear medicine services, CNEN 3.05 (Resolution 159/2013) and included objects covered in waterproof plastic material, barite-shielded walls, doors with $3 \mathrm{~mm}$ lead slides, armored fixed screen with $4 \mathrm{~cm}$ barite and lead glass for patient visualization, and paviflex bedroom floor and bathroom with rounded corners to facilitate decontamination.

The tailings deposit area, considered as a radioactive source (Figure 3, item 10), has a capacity of 770 liters $(1.40 \times 1.10 \times 0.80 \mathrm{~m})$, and in the vicinity is a corridor that includes a free area (1), purge (2), and reception (3). In this radiometric survey, to determine the equivalent dose emitted by the deposit, Equation 3 adopted: Usage factor (U) 1, occupational factor (T) $1 / 4$ for the nursing post (item 1) and $1 / 20$ for the corridor and purge (items 1, 2, 3, and 4). Considering areas of partial occupancy of people traffic, the equivalent dose of $0.01 \mathrm{mSv}$ / week was found in the contour region of the source. A worker at the nursing post of Figure 3 (item 11), working 40 weekly hours, would receive a monthly dose of $0.01 \mathrm{mSv}$. In comparison to the CNEN standard, this value for occupationally exposed workers cannot exceed $0.4 \mathrm{mSv} / \mathrm{wt}$ and for individuals of the public $0,02 \mathrm{mSv} / \mathrm{wt}$ (CNEN 3.01). However, although the deposit has walls surrounding the nursing post, it shows that its shielding makes a good attenuation to the radiation coming from the radioactive waste.

To determine the Accumulated Effective Dose (AED) of the occupationally exposed workers who are responsible for iodine therapy, this research included documentary analysis of the dose records of workers exposed to ionizing radiation from the years 2015 to 2017 . Figures 4, 5, and $6(\mathrm{ab})$ represent the exposure rate of these professionals per month.

Figure 4 - Cumulative effective dose $(\mathrm{mSv})$ by OEI in 2015. EF $=$ Nurses, MN $1=$ Nuclear Physician 1 , and $\mathrm{T}=$ Technicians

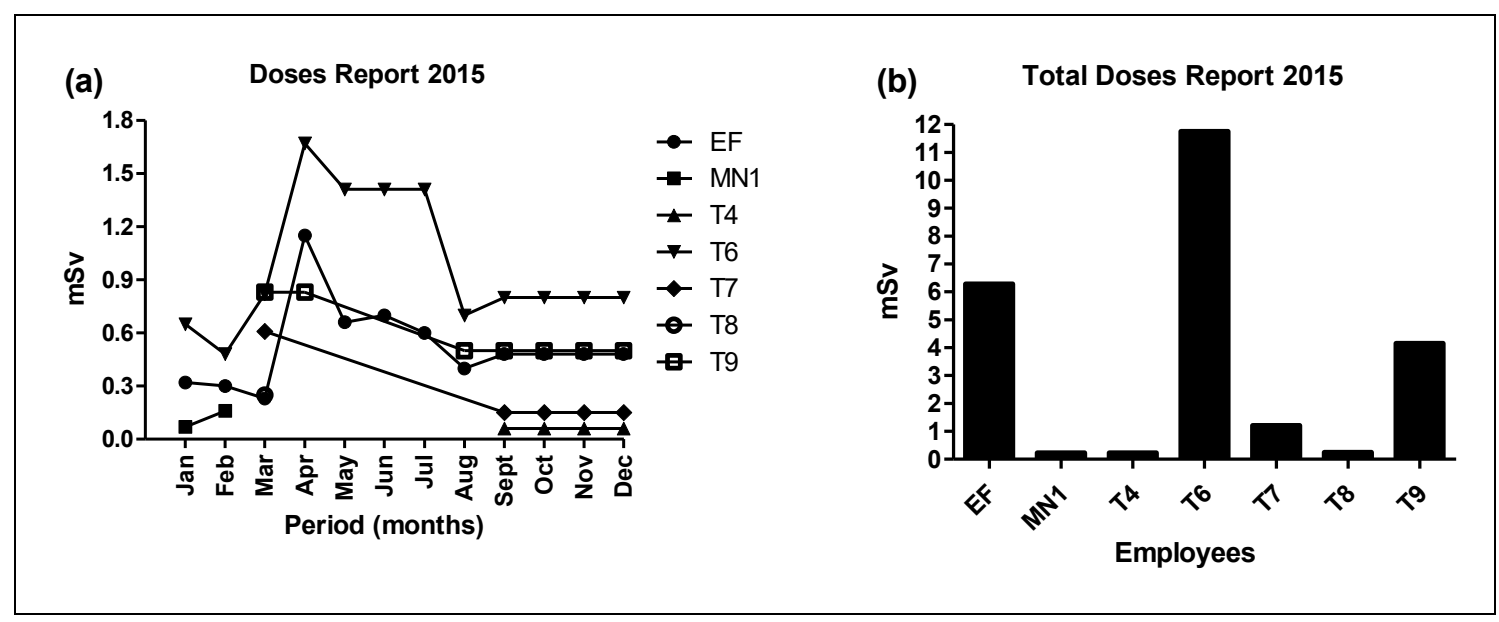

Source: Prepared by the authors 
Figure 5 - Cumulative effective dose $(\mathrm{mSv})$ by OEI in the clinic in 2016. EF $=$ Nurses, $\mathrm{T}=$ Technicians

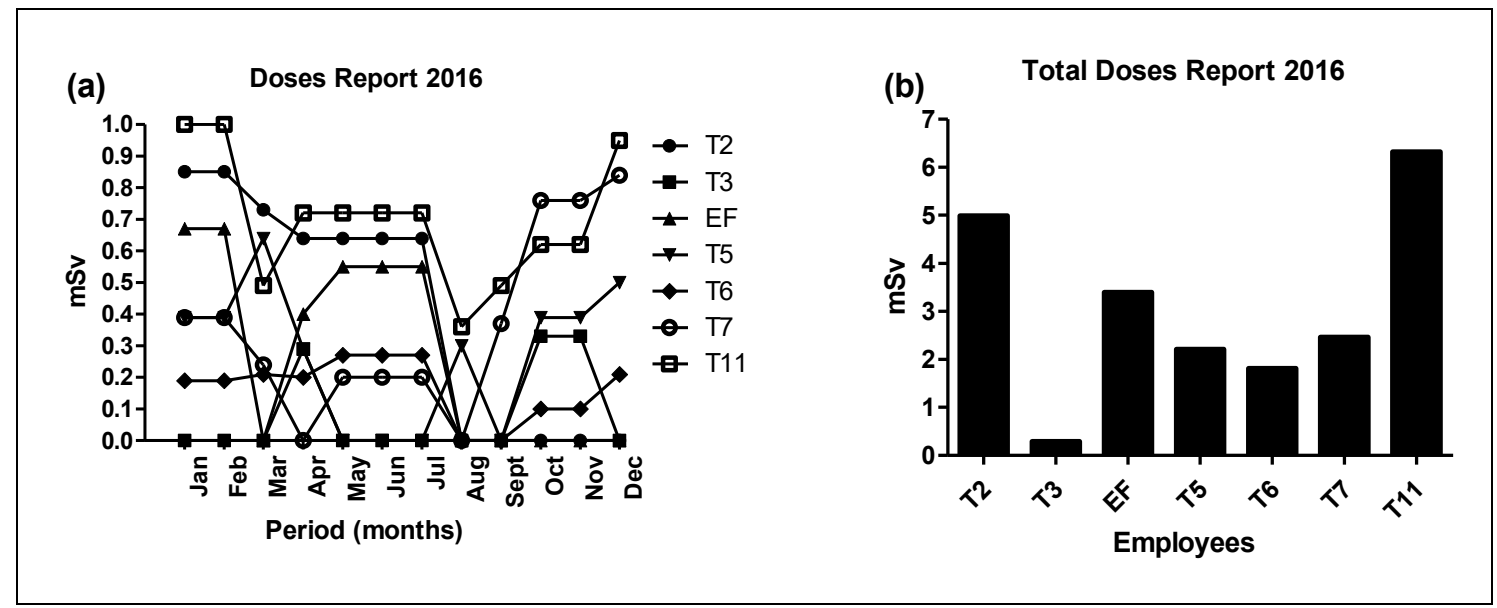

Source: Prepared by the authors

Figure 6 - Cumulative effective dose (mSv) by OEI in 2017. NM=Nuclear Medicine, $\mathrm{P}=\mathrm{Physicians}, \mathrm{T}=\mathrm{Tech}$ nicians, $\mathrm{N}=$ Nurses, $\mathrm{GS}=$ General Services, $\mathrm{ND}=$ Doses $\leq$ 0,20 $\mathrm{mSv}$.

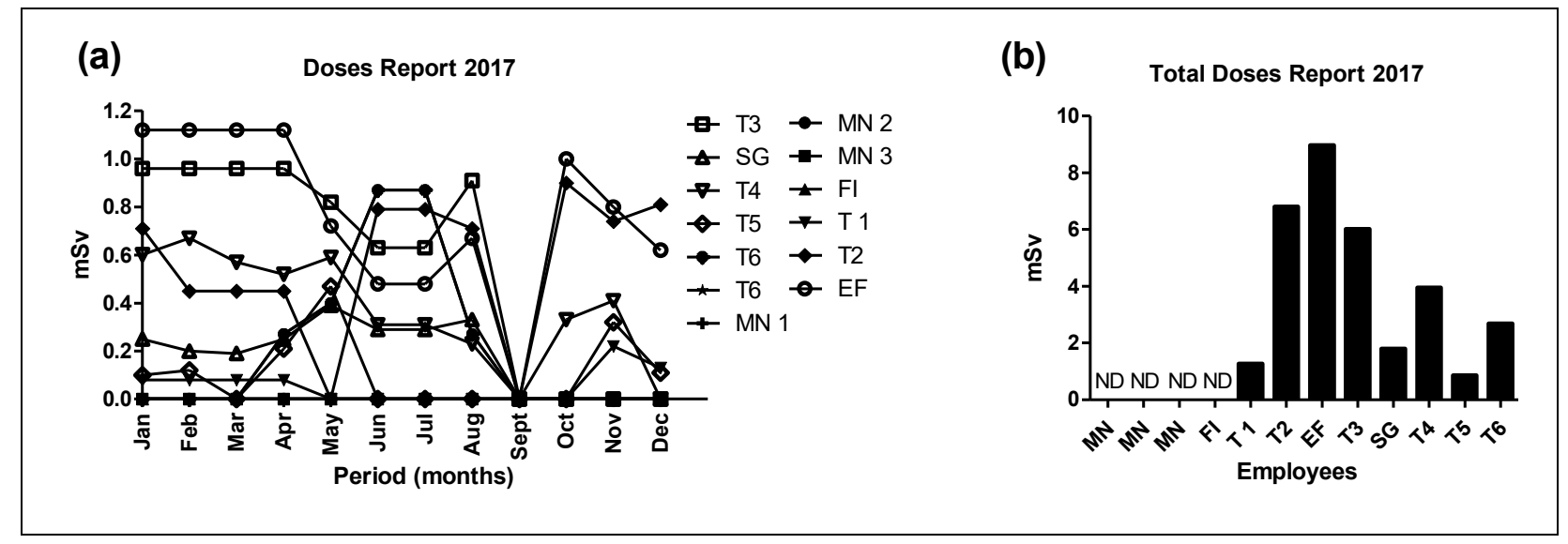

Source: Prepared by the authors

Then, they analyzed the doses of the OEI, which are in accordance with the levels of the dose acceptable to the norm NN 3.01 of CNEN.

The studies by Tomasina et al. (2010) showed that the sectors receiving the highest doses in descending order are radiation oncology, nuclear medicine, hemodynamics, and radiodiagnosis. In the same study, which analyzed dosimeters of workers from 2003 to 2006, the NM workers also did not exceed the annual limits of references, but the desirable scenario would be of the workers of that area remaining unexposed to the values of radiation. It is known that even values of small doses over the years can induce biological effects such as the stochastic effect generated by ionizing radiation.

In the present study, Figure $4(\mathrm{ab})$ shows that the greatest CED of 2015 was Technical - T6 employees $11.75 \pm$ $0.10 \mathrm{mSv}$ and Nurse $-\mathrm{N} 6.28 \pm 0.11 \mathrm{mSv}$. In the same year, it was also noticed that their dosimeters in some months registered monthly values above $1.20 \mathrm{mSv}$, which is considered as the index of the investigation. For values lower than 
$0.20 \mathrm{mSv}$, the company responsible for reading the dosimeters uses the acronym BG (background), considering low dose of radiation.

The procedure, adopted by the NM team to protect the workers who reached the level of investigation, was to change the sector and routine of service. It was noted that in the years afterwards, no OEI had a high effective dose during the month.

For the year 2016, Figure $5(\mathrm{ab})$ shows that the largest DEA was for the Technical - T11 employee of $6.32 \pm$ $0.03 \mathrm{mSv}$ and in 2017 in Figure $6(\mathrm{ab})$, this parameter was evaluated for the Nurse $-\mathrm{N}$ and Technical - T3 with $6.83 \pm$ $0.50 \mathrm{mSv}$. In all years, it was observed that technicians had high dosimeter as compared to other professionals, but this does not mean that their values reached the limit accepted by CNEN, which is $20 \mathrm{mSv}$ - the annual dose limit for OEI.

In Budecheski's study (2016), which was carried out in two clinics in Curitiba (PR), the technicians presented higher AEDs in relation to the other members of the team, with values of $16.8 \mathrm{mSv}$.

One of the reasons to justify why this professional received the highest dose of radiation is that he did most of the routine work in the clinic with the use of unsealed sources, such as elution of the $99 \mathrm{mTc}$ generator, preparation of the radiopharmaceutical kits, adding the drug to the radioactive material to be administered to the patients, and positioning the patient already administered with radioactive material for image generation. According to a study by Oliveira (2016), the length of time in the preparation room, known as the hot room, also tends to increase the accumulated dose, since this room is one of the sites with the highest radiometric levels.

For the years 2015 to 2017, Figures 4 and 5 (ab) show that nursing professionals presented annual doses of $6.28 \pm 0.11 \mathrm{mSv}$ and $6.83 \pm 0.50 \mathrm{mSv}$, respectively. One of the justifications may be that in addition to being responsible for the intravenous administration of radiopharmaceuticals in patients, they also administered iodine-131 in patients to treat metastases of differentiated thyroid carcinoma, with activity above $30 \mathrm{mCi}$.

For the group of nuclear physicians, only the year 2015 was recorded, as shown in Figure 4b. The largest dose found was $0.23 \pm 0.04 \mathrm{mSv}$, from Nuclear Physician - MN1. According to Budescheski (2016), nuclear physicians had doses well below the technical and nursing team, which is justified by the fact that physicians are not present during the administration of radiopharmaceuticals to patients and when the patients undergo myocardial examinations.

There has been no record for physicists in the last three years. In fact, these professionals do not routinely stay in the hot room, as reported by Oliveira (2016) in their research, which shows that the longer the stay, the higher the radiation dose received, which is the largest dose contribution factor ever accumulated.

\section{Conclusion}

The management of radioactive waste consists of several steps that cover the generation to the destination of the deposit and take into consideration the collection and segregation of the various types, transport, characterization, treatment, storage, decay, and final dispatch.

It was concluded that the hospital under study met the requirements of the CNEN-6.05 standard and that the conditions of storage and disposal were satisfactory. Despite the lack of data due to the failure of the inventory, with the use of the equations, it was found that the rate of exposure of the discard was lower than the allowable $2 \mu \mathrm{Ci} / \mathrm{kg}$, and with the amount of radioactive waste produced, 90 days is sufficient for the decay of I131, in compliance with normative recommendations.

Patients with doses higher than $200 \mathrm{mCi}$ required 36 to 48 hours before being discharged from the hospital. For those patients, the exposure rates were higher than the tolerable upper limit of $3 \mathrm{mR} / \mathrm{h}$, although some doubts were raised 
as contaminated surfaces influenced the monitoring result. It was observed that there is indeed influence, but it is not significant enough to define whether or not the patient can be released. This study suggests that the place where such release occurs is not a determinant for the release of patient discharge.

The study also demonstrated that exposure rates through radiometric survey, as well as providing useful information on the issue of radiation protection and exposure of workers and future contact with family members, serve as further corroborating evidence that such treatment can be performed outside of the outpatient setting.

With the help of the radiometric survey, one could see that the temporary storage site of the waste / deposit had shielding and this was able to attenuate all areas around the hospital mediations.

This study demonstrated that exposure rates through radiometric survey and management of radioactive waste produced by patients under treatment with iodine-131 are being conducted safely. When an effective dose is found in an employee, rotation among professionals in each area should be adopted to minimize the AED received.

With regard to the disposal of liquid wastes, although it was not possible to verify their concentration at the time of sewage, it is estimated that the time taken from the hospital sewage to the treatment plant, which is approximately 4 $\mathrm{km}$, is sufficient to reach the permitted value of $9.3 \mathrm{~Bq} / \mathrm{m} 3$ annually (CNEN $6.05 / 2014$ ), but this will be have to be further investigated to verify whether there are environmental impacts and damage to public health.

\section{Acknowledgments}

The authors thank the members of the hospital Jorge Moisés and Cledson Camilo Souza Silva, physicists specialized in radiotherapy, Simone Baldez de Oliveira, nurses, and the CEUMA University.

\section{References}

ADUAN, S. A.; BRAGA, F. S.; ZANDONADE, E.; SALlES, D. C.; NOIL, A. M.; LANGE, L. C. Avaliação dos resíduos de serviços de saúde do Grupo A em hospitais de Vitória (ES), Brasil. Engenharia Sanitária e Ambiental, Rio de Janeiro, v. 19, n. 2, p. 413 420, 2014.

ANDRÉ, S. C. S.; VEIGA, T. B; TAKAYANAGUI, A. M. Geração de resíduos de serviços de saúde em hospitais do município de Ribeirão Preto (SP), Brasil. Engenharia Sanitária Ambiental, v.21 n.1, p.123-130, 2016.

ANVISA; Agência Nacional de Vigilância Sanitária. Resolução da Diretoria Colegiada da ANVISA - RDC 306. Disponível em: http://portal.anvisa.gov.br/documents/33880/2568070/res0306_07_12_2004.pdf/95eac678-d4414033-a5ab-f0276d56aaa6, 2014.

BERERHI, C. A. R. Radiation exposure levels in relatives of patients after radioiodine therapy. SQU Journal for Scientific Reseasch, Medical Sciences, College of Medicine. Sultan Qaboos University, n. 2, p. 87-90, 2000.

BRASIL. Constituição da República Federativa do Brasil. Disponível em: https://www2.senado.leg.br/bdsf/ bitstream/handle/id/518231/CF88_Livro_EC91_2016.

BUDESCHESKI, S. O; SILVA, F. L; BADELLI, J. C. Avaliação dosimétrica de indivíduos ocupacionalmente expostos (IOE) em Medicina Nuclear. Revista Tecnhoeng, v. 1, n¹3, p. 92-111, 2016.

CAMPOS, Rafael Ferreira. Avaliação da contribuição da contaminação de superfícies do quarto terapêutico na medida da taxa de exposição de pacientes de radioiodoterapia. TCC (Pós-Graduação em Proteção Radiológica e Segurança de Fontes Radioativas) - Instituto de Radioproteção e Dosimetria - CNEN. Rio de Janeiro, p.33. 2015.

CHANG, J. C. M; MOREIRA, J. P. Tratamiento con yodo radiactivo en hipertiroidismo. Revista Hosp Clin Univ Chile, v. 25, p. $285-90,2014$. 
COMISSÃO NACIONAL DE ENERGIA NUCLEAR (CNEN). Gerência de Rejeitos Radioativos de Baixo e Médio Níveis de Radiação. Norma CNEN NN 6.05, Resolução CNEN 167/14.

COMISSÃO NACIONAL DE ENERGIA NUCLEAR. Diretrizes Básicas de Radioproteção. CNEN-NN-3.01; resolução 2014.

COMISSÃO NACIONAL DE ENERGIA NUCLEAR. Requisitos de Radioproteção e Segurança para Serviço de Medicina Nuclear CNEN-NN-3.05; resolução 2013.

CONAMA - Conselho Nacional do Meio Ambiente. Resolução 358, 2005. Disponível em: http://www.mma.gov.br/ port/conama/legiabre.cfm.codlegi $=462$.

COOPER, D. S; Doherty, G. M; HAUGEN, B. R; KLOOS, R. T; LEE, S. L; MANDEL, S. J; MAZZAFERRI, E. L; MCIVER, B. SHERMAN, S. I, TUTTLE, R. M. Management guidelines for patients with thyroid nodules and differentiated thyroid câncer. Thyroid. n. 16, p. 1-33, 2006.

CORONHO, V.; PETROIAANU, A.; SANTANA, E. M.; PIMENTA, L. G. Tratado de endocrinologia e cirurgia endócrina. $1^{\circ}$ edição; Rio de Janeiro: Guanabara Koogan, 2001; p. 466-77.

DIAS GL; SARTURI F; CAMPONOGARA S; et al. Análise da taxa de geração de resíduos de serviços de saúde em um hospital universitário. Rev Fund Care Online. 2017, v. 9, n. 1, p. 92-98. DOI: http://dx.doi.org/10.9789/21755361.2017.v9i1.92-98

International Atomic Energy Agency. Nuclear Medicine Resources Manual; International Atomic Energy Agency: Vienna, Austria, 2006.

International Commissioin on Radiological Protection. ICRP Publication 94, Release of Patients after Therapy with Unsealed Radionuclides; Pergamon Press: Oxford, UK, 2004.

KRAWCZYK, E.; PIÑERO-GARCÍA, F.; FERRO-GARCÍA, M. A. Discharges of nuclear medicine radioisotopes in Spanish hospitals. Journal of environmental radioactivity, v. 116, p. 93-98, 2013.

LIRA, R. F. et. al. Verificação do uso de dosímetros individuais em serviço de medicina nuclear de Pernambuco nos anos de 2002 a 2010. Brazilian Journal of Radiation Sciences, p. 26-29, 2015.

MENDES, A. A.; VEIGA, T, B; et al. Resíduos de serviços de saúde em serviço de atendimento pré-hospitalar móvel. Revista Brasileira de Enfermagem REBEN, v. 68; n. 6; p. 1122-9, 2015.

MENDONÇA, K. M. C. Avaliação dosimétrica de familiares e ambientes domiciliar de pacientes com hipertireoidismo submetidos à radioiodoterapia ambulatorial. Tese (Programa de Pós-Graduação em Tecnologias Energéticas e Nucleares do Departamento de Energia Nuclear da Universidade Federal de Pernambuco). UFPE. Recife. 2016. P.12.

OLIVEIRA et al., Modelo quantitativo de avaliação da contribuição de cada fonte radioativa na dose individual externa Hx em trabalhador de serviço de medicina nuclear. Brazilian Journal of Radiation Sciences, 2016; v. 4, n. 2, p.01-06.

PACINI F, SCHLUMBERGER, M.; DRALLE, H.; ELISEI, R. SMIT, J.W. A,; WIERSINGA, W. M.; and the European Thyroid Cancer Taskforce 2006 Consensus Statement. European consensus for the management of patients with differentiated thyroid carcinoma of the follicular epithelium. Eur J Endocrinol. 154:787- 803.

RISSATO, Maria Lúcia Iodoterapia: avaliação crítica de procedimentos de precaução e manuseio dos rejeitos radioativos gerados em unidade de internação hospitalar. Dissertação mestrado UNIARA - Araraquara, 2007;129p.

SILVA R M, SANTOS H C. Gerenciamento de Rejeitos Radioativos da Iodoterapia. Brazilian Journal of Radiation Sciences. 2015; p 5. 
TOMASINA, F et al, Vigilancia de la exposición a radiaciones ionizantes em el personal universitário de la salud. Revista Cubana de Salud Pública, v. 36, n. 1, p. 119-127, 2010.

WORLD ORGANIZATION HEALTH (WHO). Safe management of wastes from health care activities. Geneva: WHO,1999.

XAVIER, AM. Gerência de rejeitos radioativos. Rio de Janeiro: CNEN, 2012. Disponívelem:http://www.ilea.ufrgs.br/ radioisotopos/Aula\%2025\%20Julho\%20arquivo\%203.pdf

ZHANG, H; JIAO, L; CUI, S; et al. The study of external dose rate and retained body activity of patients receiving 131I therapy for differentiated thyroid carcinoma. Int.J.Environ. Res.Public Health, v. 11, 